\title{
THE ASSOCIATION BETWEEN AUDITOR SWITCHING AND AUDIT OPINION IN THE REPUBLIC OF SERBIA
}

\author{
Nemanja Stanišićc ${ }^{\star}$, Tijana Radojević ${ }^{1}$, Nenad Stanić ${ }^{1}$, Danica Rajin ${ }^{2}$ \\ ${ }^{1}$ Singidunum University, Faculty of Business in Belgrade, 32 Danijelova Street, Belgrade, Serbia \\ ${ }^{2}$ Singidunum University, Faculty of Economics, Finance and Administration, 44 Zorana Đinđića Bvd., Belgrade, Serbia
}

\begin{abstract}
:
In this study, the authors examine the association between auditor switching and type of audit opinion on a sample of companies in the Republic of Serbia. The sample comprised 4,309 non-financial companies for which auditor's reports were publicly available for the period 2010-2013. The results show that auditor switching was linked to an increased likelihood of change in the type of audit opinion. In the case when the initial audit opinion was unqualified or qualified, this increase was statistically significant. Such findings can indicate that auditor switching may lead to an improved informative value of auditor's reports, but it also raises concerns about the possibility of opinion shopping.
\end{abstract}

\section{INTRODUCTION}

During the first several years of an engagement, the quality of auditors' services typically increases, which can be attributed to the so-called learning effect. With the further passage of time, however, an overly close relationship between the client and the auditor tends to develop, which results in a decrease in the auditor's independence. Some commonly reported issues stemming from the resulting lack of independence are (IFAC, 2006):

1) self-interest threat,

2) self-review threat,

3) advocacy threat,

4) familiarity or trust threat) and

5) intimidation threat.

The available studies confirm the hypothesis that, after a certain number of periods of engagement ${ }^{1}$, the quality of auditing services starts to deteriorate (Brooks et al., 2015; Chi \& Huang, 2005). The case of Enron Corporation (2001) played an important role in raising The awareness about this issue. As a result, a number of countries ${ }^{2}$ have introduced a mandatory periodic change of auditor (so-called rotation) since then ${ }^{3}$ (Ewelt-Knauer, Gold, \& Pott, 2012).

In addition to legal requirements, auditor switching is often initiated by clients. Some of the common reasons for changing auditing firms identified in the existing literature

1 This period is estimated to be 24 years for the countries with a stronger legal environment and 12 years for other countries.

2 In the Republic of Serbia, auditor rotation is mandatory for public companies. The law on capital markets stipulates that an auditing firm can do at most 5 consecutive audits of the annual financial statements of a public company.

3 With the exception of Italy, where mandatory rotation was introduced back in 1974. include: high fees; mergers and acquisitions; preferences of shareholders (Stefaniak, Robertson, \& Houston, 2009); client's financial difficulties (Schwartz \& Menon, 1985); changes in client's management; client's dissatisfaction with the quality of auditing services (Beattie \& Fearnley, 2012); lack of good business communication (Eichenseher \& Shields, 1983); disagreement on the interpretation of accounting regulations (DeAngelo, 1982); and the need for a wider range of services (Beattie \& Fearnley, 1998). The above reasons are certainly legitimate. However, it should be noted that those reasons were identified through interviews with the management of the companies that had changed auditors. Considerable research suggests that the probability of changing auditing firms is proportional to the severity of auditing qualifications (Hudaiba \& Cooke, 2005). Therefore, in some cases, the real, unethical motive is being hidden behind the declared reasons: the opportunistic behavior of management that, in an attempt to obtain a more favorable audit opinion, appoints a different auditor (Stefaniak et al., 2009). Such behavior is called opinion shopping.

The increased awareness about the practice of opinion shopping has made the association between the change of auditors and types of audit opinion an important area of research in recent decades, with a large number of studies published on the subject. However, research in the field of auditing in the Republic of Serbia is still in its early stages (Stanisic et al., 2015; Stanisic, Stefanovic, \& Radojevic, 2016), and the link between changes in auditing companies and types of audit opinion has been studied only by Stanisic et al. (2014). Their results showed that the companies that received a positive audit opinion in one period and then subsequently changed auditing firms received a modified opinion in the upcoming period relatively more often than the companies that did not change auditors. 
The aim of this paper is to extend the aforementioned study. This time, using a significantly larger sample, we will try to derive further conclusions about the nature of the link between the change of auditor and type of audit opinion.

\section{RESULTS AND DISCUSSION}

The initial sample included 13,561 independent auditors' report issued during the period 2010-2013. All reports were obtained from the official website of the Agency for Business Registers ${ }^{4}$. The total number of companies that appeared in the sample was 4,309 . The vast majority of the companies were classified as medium-sized or large, according to the official size classification rules in place throughout the observed period; financial institutions were not included in the sample. The number of auditing firms in the sample was 64 . An overview of audit opinions according to their type and period is shown in Table 1.

Table 1. Number of opinions by type and period

\begin{tabular}{lccllr}
\hline & 2010 & 2011 & 2012 & 2013 & Total \\
\hline Unqualified & 2,329 & 2,246 & 2,442 & 2,106 & $\mathbf{9 , 1 2 3}$ \\
\hline Qualified & 913 & 900 & 1,013 & 896 & $\mathbf{3 , 7 2 2}$ \\
\hline Disclaimer & 127 & 140 & 201 & 177 & $\mathbf{6 4 5}$ \\
\hline Adverse & 9 & 15 & 22 & 25 & $\mathbf{7 1}$ \\
\hline Total & $\mathbf{3 , 3 7 8}$ & $\mathbf{3 , 3 0 1}$ & $\mathbf{3 , 6 7 8}$ & $\mathbf{3 , 2 0 4}$ & $\mathbf{1 3 , 5 6 1}$ \\
\hline
\end{tabular}

As the focus of this study was on the effects of auditor switching, the companies for which only one audit report was available were excluded from the sample. The final number of pairs of consecutive annual audit reports amounted to 8,962 , while the change of auditing firm was observed in 1,813 of them $(20.23 \%)$. All instances of auditor switching observed in the sample are presented in a form of a network diagram in Fig. 1. The size of the nodes in the diagram is proportional to the observed number of switches, where the respective auditing firm appears as either the preceding or the current auditor, while the thickness of the links between the nodes was determined based on the observed number of clients switching between the corresponding auditing firms.

All possible combinations of types of audit opinion have been summarized in a form of contingency tables and transition matrices for the observations in which the auditor remained unchanged (Table 2), as well as for the observations in which a change of auditor was recorded (Table 3). Initial opinions are presented in rows, while the subsequent opinions appear in the columns.

Preliminary examination of the cross tabulated data indicates that the companies that received a qualified opinion were, in general, more inclined to change auditors in comparison to the companies that received a positive opinion, which is consistent with the results of previous research (Hudaiba \& Cooke, 2005). Also, it appears that the mobility of the opinions increased with a change in auditing firm (percentages along the diagonal of the transition matrix are smaller within the group of companies in which a change of auditor was recorded). Changes in the opinions slightly

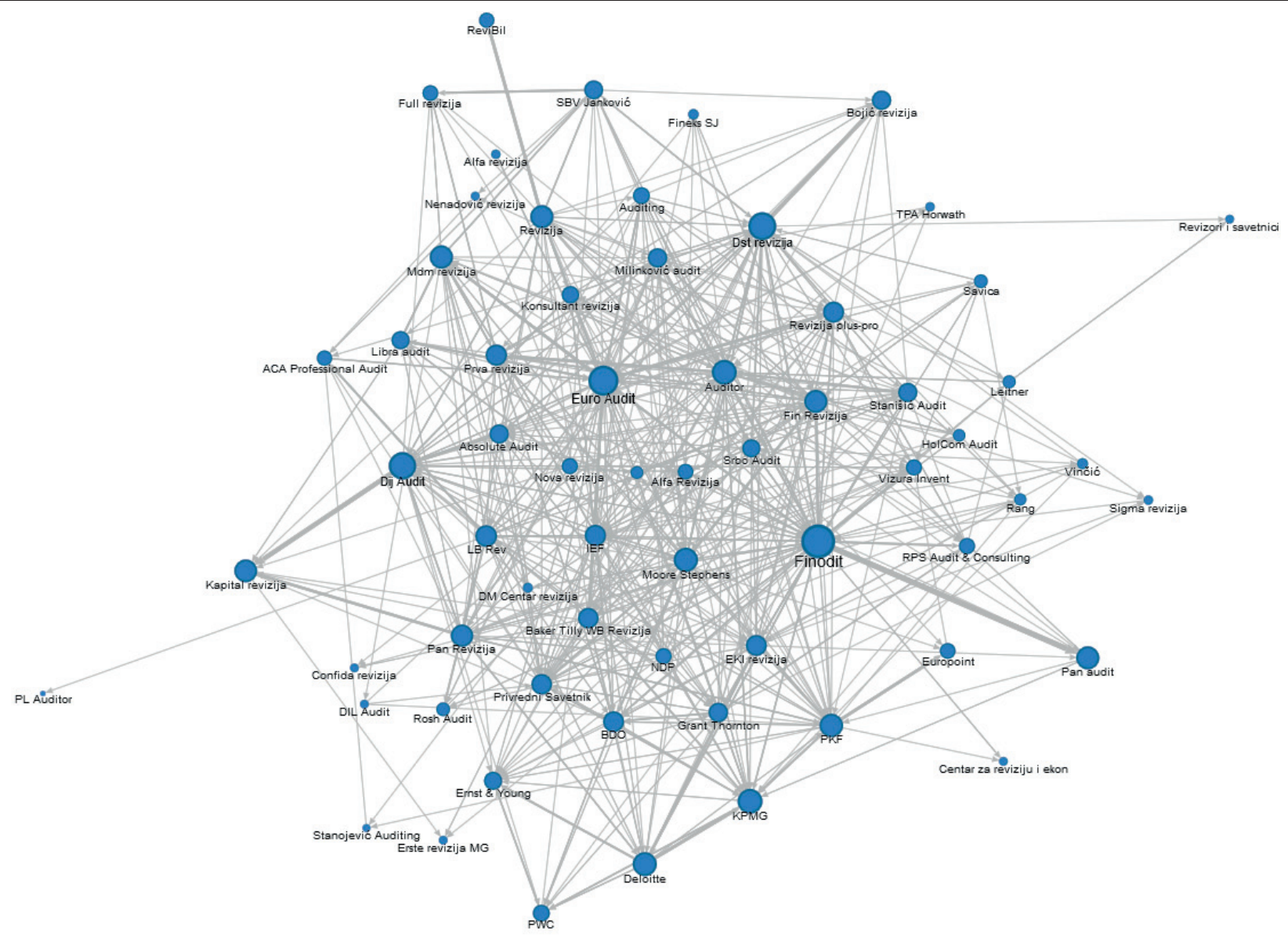

Figure 1. Switches between auditor firms in the observed sample (Google Fusion Tables Network Graph) 
Table 2. Transition matrix of types of audit opinion for observations in which the auditor remained unchanged

\begin{tabular}{lcccrr}
\hline & Unqualified & Qualified & Disclaimer & Adverse & Total \\
\hline Unqualified & 4,667 & 482 & 47 & 74 & $\mathbf{5}, \mathbf{1 0}$ \\
\hline Qualified & 364 & 1,249 & 47 & 4 & $\mathbf{2}$ \\
\hline Disclaimer & 9 & 5 & 4 & $\mathbf{6 9 2}$ & $\mathbf{1 6}$ \\
\hline Adverse & 1 & $\mathbf{1 , 7 8 3}$ & $\mathbf{2 9 2}$ & $\mathbf{3 3}$ & Total \\
\hline Total & $\mathbf{5 , 0 4 1}$ & Qualified & Disclaimer & Adverse & $\mathbf{1 0 0 \%}$ \\
\hline & Unqualified & $9.25 \%$ & $0.90 \%$ & $0.27 \%$ & $\mathbf{1 0 0 \%}$ \\
\hline Unqualified & $89.58 \%$ & $73.82 \%$ & $4.14 \%$ & $0.53 \%$ & $\mathbf{1 0 0 \%}$ \\
\hline Qualified & $21.51 \%$ & $20.35 \%$ & $74.03 \%$ & $1.73 \%$ & \\
\hline Disclaimer & $3.90 \%$ & $31.25 \%$ & $25.00 \%$ & $37.50 \%$ &
\end{tabular}

Table 3. Transition matrix of types of audit opinion for the observations in which a change of auditor was recorded

\begin{tabular}{|c|c|c|c|c|c|}
\hline & Unqualified & Qualified & Disclaimer & Adverse & Tota \\
\hline Unqualified & 859 & 204 & 16 & 4 & 1,083 \\
\hline Qualified & 159 & 407 & 34 & 7 & 607 \\
\hline Disclaimer & 11 & 28 & 70 & 2 & 111 \\
\hline Adverse & 2 & 2 & 5 & 3 & 12 \\
\hline \multirow[t]{2}{*}{ Total } & 1,031 & 641 & 125 & 16 & 1,813 \\
\hline & Unqualified & Qualified & Disclaimer & Adverse & Tota \\
\hline Unqualified & $79.32 \%$ & $18.84 \%$ & $1.48 \%$ & $0.37 \%$ & $100 \%$ \\
\hline Qualified & $26.19 \%$ & $67.05 \%$ & $5.60 \%$ & $1.15 \%$ & $100 \%$ \\
\hline Disclaimer & $9.91 \%$ & $25.23 \%$ & $63.06 \%$ & $1.80 \%$ & $100 \%$ \\
\hline Adverse & $16.67 \%$ & $16.67 \%$ & $41.67 \%$ & $25.00 \%$ & $100 \%$ \\
\hline
\end{tabular}

leaned towards better opinions with, of course, exceptions in the case of a positive initial opinion.

In order to conduct a formal statistical analysis, we have specified four pairs of hypotheses. The null hypotheses claimed that, within the observed initial audit opinions (rows in the table), there would be no significant differences in the proportions of the subsequent audit opinions between the observations in which changes of auditor were recorded and the observations in which the auditor remained unchanged. The alternative hypotheses stated that significant differences would exist within the groups. Given the small number of observations with a negative opinion, hypotheses testing was conducted using the Fisher's test of independence (Fisher's exact test), namely its implementation (Mehta \& Patel, 2010) in the statistical software SPSS (IBM Corporation, 2013). The values of the significance parameters $(p)$ obtained from the Fisher's tests are shown in the second column of Table 4.

Table 4. Results of the hypotheses testing

\begin{tabular}{lccc}
\hline $\begin{array}{c}\text { Pairs of transition } \\
\text { matrix rows sorted by } \\
\text { ascending } \boldsymbol{p} \text { value }\end{array}$ & $\begin{array}{c}\text { Fisher's } \\
\text { exact test } \mathbf{p} \\
\text { value (two } \\
\text { sided) }\end{array}$ & $\begin{array}{c}\text { Adjusted } \\
\text { a level }\end{array}$ & $\begin{array}{c}\text { Ho hy- } \\
\text { pothesis } \\
\text { status }\end{array}$ \\
\hline First pair of rows & 0.00000 & 0.0125 & Rejected \\
\hline Second pair of rows & 0.00735 & 0.0167 & Rejected \\
\hline Third pair of rows & 0.07340 & 0.0250 & $\begin{array}{c}\text { Not } \\
\text { rejected }\end{array}$ \\
\hline Fourth pair of rows & 0.60304 & 0.0500 & $\begin{array}{c}\text { Not } \\
\text { rejected }\end{array}$ \\
\hline
\end{tabular}

Taking into consideration that four hypotheses were tested, we used Holm's (1979) procedure of sequential testing to control the familywise error rate. The adjusted values of the level of statistical significance $(\alpha)$ are shown in the third column in Table 4. The procedure was stopped after the third iteration as the following condition was met:

$$
\hat{p}(3)>\frac{0,05}{4-2}
$$

Consequently, the first two hypotheses were rejected, while there was not enough evidence to support the rejection of the third and the fourth hypotheses.

The results show that companies that had a positive or a qualified audit opinion had a significantly less chance of maintaining the same type of audit opinion if they changed auditors. Even though the identical pattern was observed in the other two groups, the effect was not statistically significant. It is important, however, to highlight that the main limitation of this study was the sample size of the observations with disclaimer or negative initial opinions. Due to the limited statistical power of the two corresponding tests, we must accept the possibility that the mobility of opinions was improved among all groups of initial opinion.

The results can be interpreted from at least two different perspectives. From an optimistic perspective, a more thorough audit of the new client's financial reports, rendered for either precautionary reasons or with the purpose of demonstrating a superior service quality, may be considered the primary cause of the increased change rate in audit opinion after changing auditors. On the other hand, from a pessimistic point of view, the argument of opinion shopping appears to be more convincing. This view is supported by the aforementioned observation that companies with modified initial opinions were relatively more likely to change auditors, with the subsequent opinions being more frequently upgraded than downgraded. The possibility of opinion shopping should not be excluded even in cases in which clients do 
not receive more favorable audit opinions after a change of auditor because, as pointed out by Lennox (2000), opinions could be even worse if the change did not occur. It seems that both of these phenomena occur in certain proportions in practice. The estimation of these proportions represents a significant challenge for future research in this area.

\section{CONCLUSIONS}

The main outcomes of this study are, in fact, guidelines for future research that should aim to examine:

1) the extent to which relatively worse audit opinions of companies that opt for a change of auditor are actually justified and

2) the extent to which changes in the quality of financial statements coincide with changes in auditors' opinions, considering the companies that changed and companies that didn't change auditors separately.

The results of the first topic of inquiry will shed light on the intentions of management, i.e., the extent to which their intentions are genuinely directed towards high-level audit services or opinion shopping. The results of the second focus area will indicate the success level of realization of these intentions. In order to achieve the above -given objectives, it is necessary to employ the methodological tools developed in the field of earnings management, as demonstrated by Bartov, Gul and Tsui (2000).

\section{REFERENCES}

Bartov, E., Gul, F. A., \& Tsui, J. S. L. (2000). Discretionaryaccruals models and audit qualifications. Journal of Accounting and Economics, 30(3), 421-452. doi:10.1016/ S0165-4101(01)00015-5

Beattie, V., \& Fearnley, S. (1998, September 1). Audit market competition: auditor changes and the impact of tendering. British Accounting Review. Academic Press. Retrieved from http:// eprints.gla.ac.uk/786/1/BrAccRev30\%283\%29261-289.pdf

Beattie, V., \& Fearnley, S. (2012). The Importance of Audit Firm Characteristics and the Drivers of Auditor Change in UK Listed Companies. Accounting and Business Research, 25(100), 227-239. doi:10.1080/00014788.1995.9729912

Brooks, L., Cheng, C., Johnston, J., \& Reichelt, K. (2015). Estimates of Optimal Audit Firm Tenure across Different Legal Regimes. Retrieved from http://www.af.polyu.edu.hk/ files/cafr2015/36_Estimates of optimal audit firm tenures across difference legal regimes.pdf

Chi, W., \& Huang, H. (2005). Discretionary accruals, audit-firm tenure and audit-partner tenure: Empirical evidence from Taiwan. Journal of Contemporary Accounting \& Economics. Retrieved from http://www.sciencedirect.com/science/ article/pii/S1815566910700035
DeAngelo, L. E. (1982). Mandated successful efforts and auditor choice. Journal of Accounting and Economics, 4(3), 171-203. doi:10.1016/0165-4101(82)90008-8

Eichenseher, J., \& Shields, D. (1983). The correlates of CPA-firm change for publicly-held corporations. Auditing: A Journal of Practice and Theory. Retrieved from https://scholar. google.com/scholar?hl=en\&q=eichenseher+and+shields+ $1983 \& b \operatorname{btnG}=\& a s \_s d t=1 \% 2 C 5 \& a s \_s d t p=\# 0$

Ewelt-Knauer, C., Gold, A., \& Pott, C. (2012). What do we know about mandatory audit firm rotation? Edinburgh: ICAS. Retrieved from https://www.icas.com/_data/assets/pdf_file/0016/100843/ICAS-Mandatory-Audit-FirmRotation-Report.pdf

Holm, S. (1979). A simple sequentially rejective multiple test procedure. Scandinavian Journal of Statistics, 6(2), 65-70.

Hudaib, M., \& Cooke, T. E. (2005). The Impact of Managing Director Changes and Financial Distress on Audit Qualification and Auditor Switching. Journal of Business Finance \& Accounting, 32(9-10), 1703-1739. doi:10.1111/j.0306686X.2005.00645.x

IBM Corporation. (2013). IBM SPSS Statistics for Windows. Armonk, NY.

IFAC. (2006). Code of Ethics for Professional Accountants. London: International Federation of Accountants.

Lennox, C. (2000). Do companies successfully engage in opinion-shopping? Evidence from the UK. Journal of Accounting and Economics, 29(3), 321-337. doi:10.1016/S01654101(00)00025-2

Mehta, C. R., \& Patel, N. R. (2010). IBM SPSS Exact Tests. IBM Software Group. Retrieved from ftp://public.dhe.ibm.com/ software/analytics/spss/documentation/statistics/20.0/en/ client/Manuals/IBM_SPSS_Exact_Tests.pdf

Schwartz, K., \& Menon, K. (1985). Auditor switches by failing firms. Accounting Review. Retrieved from http://www.jstor.org/stable/246789

Stanišić, N., Mizdraković, V., Radojević, T., \& Stanić, N. (2015). Defining Second-tier Audit Firms in Serbia: in Search for the Small Four. The European Journal of Applied Economics, 12(2), 35-43. doi:10.5937/ejae12-9214

Stanišić, N., Petrović, Z., Vićentijević, K., \& Mizdraković, V. (2014). Auditor Switching and Qualified Audit Opinion: Evidence from Serbia. In Proceedings of the 1st International Scientific Conference - Sinteza 2014 (pp. 552-558). Belgrade, Serbia: Singidunum University. doi:10.15308/ sinteza-2014-552-558

Stanišić, N., Stefanović, N., \& Radojević, T. (2016). Determinants of the cost of debt in the Republic of Serbia. Belgrade, Serbia.

Stefaniak, C. M., Robertson, J. C., \& Houston, R. W. (2009). The causes and consequences of auditor switching: A review of the literature. Journal of Accounting Literature, 28, 47-121. Retrieved from http://search.proquest.com/openview/cc97 6194a4075a17bba674d5b2348e33/1?pq-origsite=gscholar

Toplak, A. (2014). Revizorske kuće u Srbiji. Novi Sad. Retrieved from http://www.dmi.uns.ac.rs/site/dmi/download/master/primenjena_matematika/AnaToplak.pdf

\section{VEZA IZMEĐU PROMENE REVIZORSKE KUĆE I VRSTE REVIZORSKOG MIŠLJENJA U REPUBLICI SRBIJI}

\section{Apstrakt:}

U ovom radu ispituje se povezanost između promene revizorske kuće i vrste revizorskog mišljenja na uzorku privrednih društava iz Republike Srbije. Uzorak je činilo 4.309 nefinansijskih društava koja su imala javno dostupne izveštaje nezavisnog revizora za period između 2010. i 2013. godine. Rezultati pokazuju da je promena revizorske kuće povezana sa većom verovatnoćom promene vrste revizorskog mišljenja. U slučajevima kada je inicijalno mišljenje bilo pozitivno ili sa rezervom, ova razlika u verovatnoći je i statistički značajna. Ovakav nalaz može ukazivati na to da promena revizorske kuće povećava informativnost revizorskih izveštaja, ali i da postoji praksa kupovine mišljenja.

\section{Ključne reči:}

revizorsko mišljenje,

promena revizora,

Republika Srbija. 